\title{
EVALUATION OF TERRESTRIAL LASER SCANNER ACCURACY IN THE CONTROL OF HYDROTECHNICAL STRUCTURES
}

\author{
ZBIGNIEW MUSZYŃSKI \\ Wrocław University of Science and Technology, Faculty of Geoengineering, Mining and Geology, Wrocław, Poland, \\ e-mail: zbigniew.muszynski@pwr.edu.pl
}

JAROSŁAW RYBAK

Wrocław University of Science and Technology, Faculty of Civil Engineering, Wrocław, Poland, e-mail: jaroslaw.rybak@pwr.edu.pl

\begin{abstract}
In many cases of monitoring or load testing of hydrotechnical structures, the measurement results obtained from dial gauges may be affected by random or systematic errors resulting from the instability of the reference beam. For example, the measurement of wall displacement or pile settlement may be increased (or decreased) by displacements of the reference beam due to ground movement. The application of surveying methods such as high-precision levelling, motorized tacheometry or even terrestrial laser scanning makes it possible to provide an independent reference measurement free from systematic errors. It is very important in the case of walls and piles embedded in the rivers, where the construction of reference structure is even more difficult than usually. Construction of an independent reference system is also complicated when horizontal testing of sheet piles or diaphragm walls are considered. In this case, any underestimation of the horizontal displacement of an anchored or strutted construction leads to an understated value of the strut's load. These measurements are even more important during modernization works and repairs of the hydrotechnical structures.

The purpose of this paper is to discuss the possibilities of using modern measurement methods for monitoring of horizontal displacements of an excavation wall. The methods under scrutiny (motorized tacheometry and terrestrial laser scanning) have been compared to classical techniques and described in the context of their practical use on the example hydrotechnical structure. This structure was a temporary cofferdam made from sheet pile wall. The research continuously conducted at Wroclaw University of Science and Technology made it possible to collect and summarize measurement results and practical experience. This paper identifies advantages and disadvantages of both analysed methods and presents a comparison of obtained measurement results of horizontal displacements. In conclusion, some recommendations have been formulated, which are relevant from the point of view of engineering practice.
\end{abstract}

Key words: geodetic measurements, horizontal displacements, motorized tacheometry, LIDAR

\section{INTRODUCTION - THE NEED TO USE GEODETIC SURVEYS}

In recent years, a number of investments related to the modernization of waterways have been made in Poland. The purpose of these actions was to increase the share of inland waterway transport in the overall transportation system, which is currently based mainly on the road and rail means. An additional purpose of these renovation works was to increase the protection against floods. This is a typical problem in many European countries, where the old hydrotechnical facilities, located especially in city centres, are too small (they cannot contain the flood wave) and need to be redeveloped as soon as possible.
Hydrotechnical objects are specific structures, which are subject to a series of unfavourable factors while operating. The most important ones include variable pressure of water depending on the water damming level, sudden surges resulting from rainfall and possible unfavourable geological and soil-water conditions that reduce stability of the structure. To ensure safety of people, property and environment, the hydrotechnical objects must be regularly inspected during their operation. The aspects that need to be controlled include the measurements of horizontal and vertical displacements, carried out using geodetic methods. Systematic control of the spatial position and shape of the structure under testing in its selected checkpoints ensures operational safety [3]. For this reason, it is important to ensure high accuracy of the 
measurement results. To fulfil this condition, modern measurement techniques are more frequently used and integrated with various types of sensors recording the state of the monitored structure.

\section{SELECTED GEODETIC TECHNIQUES FOR DISPLACEMENT DETERMINATION OF HYDROTECHNICAL STRUCTURE}

The variety of techniques gives enough space for proper selection of an appropriate measurement technique, which depends on:

a) the features of the controlled hydrotechnical structure,

b) the scope and detail of the data required,

c) the expected values of displacements and the required accuracy of their determination,

d) the dynamics of the structure (rapidity of changes in shape or position), which limits the duration of a single measurement and the frequency of further measurements).

In the following paragraphs the essential geodetic techniques used for the determination of displacements of hydrotechnical objects with particular regard to the terrestrial laser scanning and the possibility of integrating various measuring techniques were described.

Geometrical precise levelling is the most popular and the most accurate method for determination of vertical displacements. Currently, the digital levelling instruments are used, which perform the readouts automatically based on the analysis of the image of the invar bar coded rod on the staff. The typical accuracy reaches $\pm 0.3 \mathrm{~mm}$ per $1 \mathrm{~km}$ of double highprecision levelling. In designing of levelling network the main problem is to properly assess the zone of the object impact. Reference benchmarks should be located as far as possible and beyond this zone. At the same time, long distances between reference points increase the measurement errors. In selection of the location of reference benchmarks also geotechnical conditions, such as the soil type and the information of the water table alterations, should be considered. During the development of the periodic measurement results, the most important step is a correct identification of fixed reference points. In some situations related to hydrotechnical facilities, more sophisticated calculation procedures are needed, such as robust estimation [9].

The basic technique for determining horizontal displacements is an angular-linear measurement per- formed using precise electronic tachometers. Sometimes this technique is also used to determine vertical displacements when precision levelling cannot be applied. For the important constructions, the most popular seems structural monitoring. That is a modern system combining geodetic techniques with the relative measurement of displacement as well as with various types of sensors recording the behaviour of the structure, e.g., typical inclinometers, high-precision electronic inclinometers, piezometers. This system makes it possible to automatically record the state of the structure at predefined time intervals. After automatic calculation, the obtained values of displacement are compared with the permissible values (with the possibility of automatic alarm signalling), visualized and sent remotely to relevant supervisory bodies. The main components of the system are the motorized electronic total stations, which have the function of the automatic target detection (indicated by geodetic prisms). The total stations are usually placed at the fixed reference points, in special glazed containers equipped with air conditioning and the source of power supply. Those containers protect the instrument from the changing weather conditions and enable its continuous operation [5].

Subsequent technique for displacement determination is the GNSS positioning, which is especially suitable for very large areas. This technique may be used separately or be a part of structural monitoring for the control of total station stability in relation to other reference points. The GNSS receivers operating in static mode are usually placed at the reference points in order to control the stability of their position. If stability of the tacheometric stations cannot be ensured, the stations are integrated with the GNSS receivers in order to record their position [12]. The receivers operating in the RTK mode are also installed at the key control points, where they enable the recording of the dynamic changes of the structure even at the intervals smaller than one second [13].

Some aspects of combining measurement techniques and designing continuous monitoring system for Hydro Power Dams are widely described in [11]. The author have shown a simulation of the combination of three GNSS receivers with two total stations. Next, the number of GNSS receivers and/or total stations was reduced. Along with the decreasing amount of instruments, the accuracy of displacement value determination also decreases. The combination of GNSS data and precise levelling data collected from geodetic monitoring of dam in Greece is shown in [4]. That dam is located within the seismically active area of central Greece. This network consists of 17 GNSS 
receivers established on the dam body and 4 receivers established at selected points on the ground surrounding the dam. The precise levelling was performed to provide displacements for 17 pillars located along the crest of the dam.

Terrestrial laser scanning is another measuring technique whose importance in engineering practice has been growing. It is a rapidly evolving technology that enables measurement of up to one million points per second. For the ScanStation C10 scanner manufactured by Leica Geosystems, a prism rotates along horizontal axis and sends the impulses of a laser beam which are reflected from the measured structure. Simultaneously, the scanner rotates along vertical axis with a predetermined steps. For each impulse the reflectorless measurement of the distance is taken, and the horizontal and vertical angles are measured. The accuracy of the single point location at the distance up to $50 \mathrm{~m}$ amounts to $\pm 6 \mathrm{~mm}$. The accuracy of the angle measurement amounts to 60 microradians and for distance measurement respectively $\pm 4 \mathrm{~mm}$. The accuracy of the surface modelled based on the point cloud is equal to $\pm 2 \mathrm{~mm}$. The density of point cloud is defined in the horizontal and vertical direction for the plane located at a given distance from the scanner. Most scanners are equipped with a high-resolution digital camera with an automatic zoom, which takes the photos of the structures under survey. It enables the archivisation of the state of the structure (also the object's temperature when the thermal cameras are used), and their realistic visualization. In the case of large structures, the separate scanner stations are connected by means of scanning the tie points indicated by special targets. It is recommended to use points from the geodetic network as the linking points.

In the case of hydrotechnical objects, the terrestrial laser scanning is used mainly for testing the large dam deformation, for estimation of concrete conditions [14] or for the assessment of roughness parameters [7]. The study by Zogg [15] provided an example of using scanning in the so-called reverse engineering understood as obtaining information about the geometry of the existing facility (dam overfall construction) in the absence of design documentation. Another example of using this technology is application of scanning to measure the geometry of river embankments described in the study [6]. Despite relatively small accuracy of determining the position of a single point, the laser scanning has great advantage. It enables registration of the condition of the whole structure. In a short time it is possible to obtain a fully metric, three-dimensional model of a hydrotechnical structure (see: [10]). What is also important, this technique is remote and usually does not require contact with the object under testing. Due to additional targets mounted on the checked structure it is possible to control displacement of selected points with a better accuracy (about $\pm 2 \mathrm{~mm}$ ).

Modern techniques of surveying may be used for fast and reliable measurement of displacement of many points in terms of pile testing [1], [2]. The role of those techniques becomes crucial when thermal factors (due to insolation) and the movements of the ground around the pile under testing at the terminal phase of test affect the results of traditional dial gauge measurements. The application of terrestrial laser scanning and other geodetic methods leads to a fast control of many points (Fig. 1). That seems to be crucial if the results are expected to be free from systematic errors related to climate conditions, ground movements and dynamic influence of works in the proximity of the performed test. It is also very important when the test is assembled in water and the construction of a reference beam is almost impossible, which is especially relevant for hydrotechnical structures.

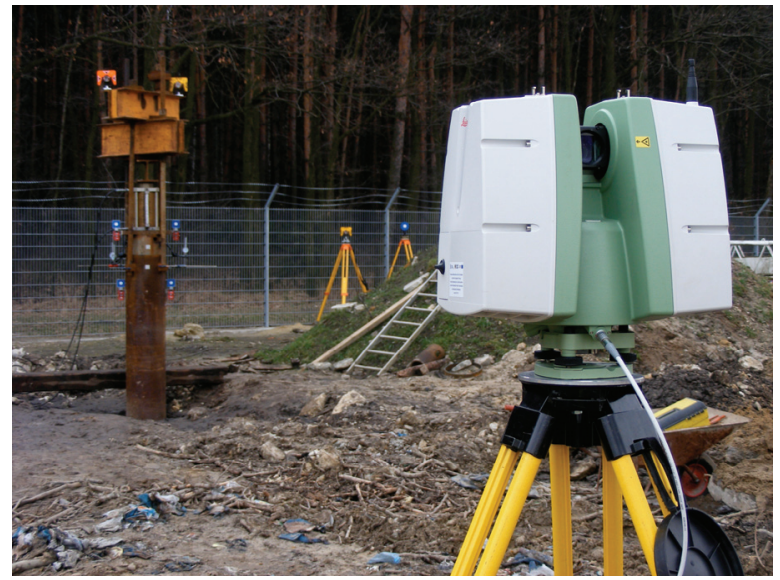

Fig. 1. Application of terrestrial laser scanning to control the vertical displacements during the self-balanced pile capacity testing

\section{BASIC INFORMATION ABOUT TESTED RESEARCH FACILITY}

The application of modern measurement techniques is recommended and successfully implemented for new hydraulic facilities and for old structures during their operation. Some problems arise when the structure is being upgraded and the construction works are being carried out. Following stages of the modernization works and the use of heavy machinery require the current adaptation of measurement net- 


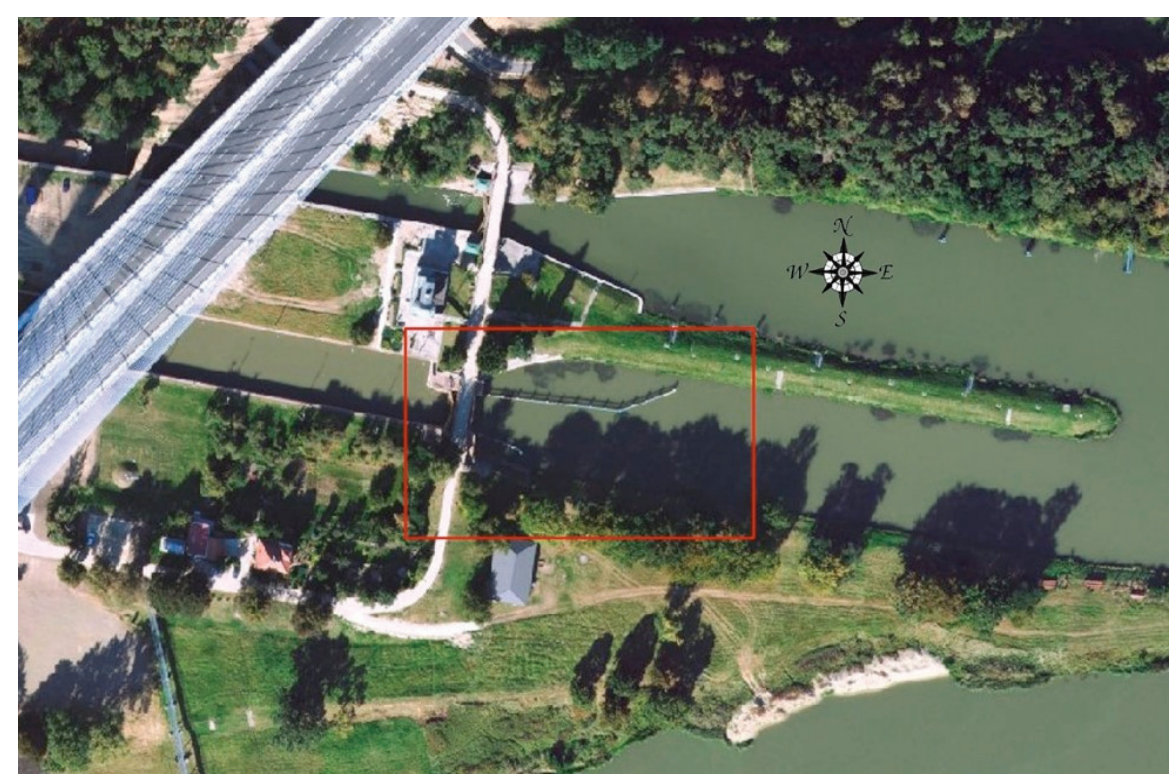

Fig. 2. The research facility: southern Rędzin sluice situated on the Odra River in Wrocław

work shape and new arrangement of instrument stations. The purpose of this paper is to show the possibilities of using the modern measurement techniques in such situation. Particular emphasis will be placed on the assessment of terrestrial laser scanning accuracy in difficult terrain conditions. As a research object, the southern Rędzin sluice was chosen. It is situated on the Odra River, in the city of Wrocław, in the south-western part of Poland (Fig. 2). The facility construction works were carried out as part of the Wrocław Floodway modernisation to protect it against flooding. The southern Rędzin sluice was built between 1914 and 1917. It is a clay, single chamber sluice with the following technical parameters:

a) usable height of the chamber and downstream lock head: $8.20 \div 8.55 \mathrm{~m}$,

b) usable height of the upstream lock head: $9.80 \div$ $10.50 \mathrm{~m}$,

c) length of the construction: $227.70 \mathrm{~m}$,

d) width of the construction: $21.00 \div 27.50 \mathrm{~m}$,

e) capacity: about $45100 \mathrm{~m}^{3}$.

One of the stages of modernisation works was the construction of a new, additional upstream lock head (adjacent to the existing head) with a segment gate. New upstream lock head was constructed under the cover of a temporary cofferdam, constructed of steel sheet piles and adjacent to the existing upstream lock head. For the construction of the cofferdam, GU 16-400 sheet piles were used, made of S270 GP steel and $17.0 \mathrm{~m}$ long. The wall of the cofferdam was anchored at the bottom (in the ground) and spread from the inside on two levels of steel pipes with a diame- ter of $610 \mathrm{~mm}$ (upper strut) and $813 \mathrm{~mm}$ (bottom strut).

\section{THE SCOPE OF GEODETIC MEASUREMENTS}

The scope of surveys discussed in this paper entailed the determination of horizontal displacements of cofferdam in a few selected sites:

a) near the inclinometric pipes,

b) at the ends of struts,

c) in selected places of steel sheet piles.

The surveying began with stabilising the points that made up the geodetic network, which consisted of six reference points, four directional points and eighteen check points. A sketch of measurement network with numbers of points for the 2 nd check survey is shown in Fig. 3. For the purposes of this work, nine measurement campaigns were carried out. The dates and the environmental conditions in which the measurements were performed are summarized in Table 1.

Geodetic measurements were made independently with the use of motorized electronic total station (TS) and Leica ScanStation C10 laser scanner. The initial measurement was made using Leica TS15 total station, while all the next ones were made using Trimble S3 total station. During each measurement (throughout the period it was made), the reference points were indicated by prisms or scanner targets mounted on tripods. Each measurement of a reference point (made by means of 
Table 1. The dates and the environmental conditions of surveying campaigns

\begin{tabular}{|c|c|c|c|c|c|}
\hline $\begin{array}{l}\text { Name } \\
\text { of survey }\end{array}$ & $\begin{array}{l}\text { Date } \\
\text { of survey }\end{array}$ & State of construction work & 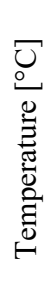 & 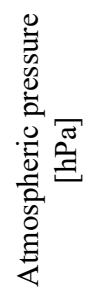 & 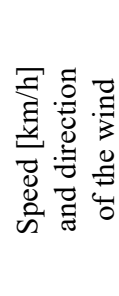 \\
\hline \begin{tabular}{|l|l} 
Initial \\
survey
\end{tabular} & $\begin{array}{l}\text { September 3, } \\
2013\end{array}$ & after assembling the upper frame and corner struts & 22 & 1019 & $13 \mathrm{NW}$ \\
\hline $\begin{array}{l}\text { 1st check } \\
\text { survey }\end{array}$ & $\begin{array}{l}\text { September 5, } \\
2013\end{array}$ & $\begin{array}{l}\text { after assembling all the upper struts and lowering the } \\
\text { water table }\end{array}$ & 24 & 1021 & $5 \mathrm{E}$ \\
\hline $\begin{array}{l}\text { 2nd check } \\
\text { survey }\end{array}$ & $\begin{array}{l}\text { September 20, } \\
2013\end{array}$ & after assembling a set of struts on the lower level & 16 & 1014 & $7 \mathrm{~W}$ \\
\hline $\begin{array}{l}\text { 3rd check } \\
\text { survey }\end{array}$ & $\begin{array}{l}\text { October 25, } \\
2013\end{array}$ & $\begin{array}{l}\text { after partially digging out inside the chamber below } \\
\text { the lower struts and simultaneously after besprinkling } \\
\text { the southern side wall of the cofferdam from the outside }\end{array}$ & 18 & 1004 & $7 \mathrm{SE}$ \\
\hline $\begin{array}{l}\text { th check } \\
\text { survey }\end{array}$ & $\begin{array}{l}\text { November 15, } \\
2013\end{array}$ & after completely digging out inside the chamber & 8 & 1010 & $2 \mathrm{E}$ \\
\hline $\begin{array}{l}\text { 5th check } \\
\text { survey }\end{array}$ & $\begin{array}{l}\text { December 27, } \\
2013\end{array}$ & preparation for concreting the bottom plate & 8 & 992 & $9 \mathrm{SW}$ \\
\hline $\begin{array}{l}\text { 6th check } \\
\text { survey }\end{array}$ & \begin{tabular}{|l} 
January 10, \\
2014
\end{tabular} & after pouring the bottom concrete plate & 8 & 996 & $24 \mathrm{~W}$ \\
\hline $\begin{array}{l}7 \text { th check } \\
\text { survey }\end{array}$ & \begin{tabular}{|l} 
February 14, \\
2014
\end{tabular} & the beginning of concreting the walls of the new lock head & 7 & 992 & $16 \mathrm{~W}$ \\
\hline $\begin{array}{l}\text { 8th check } \\
\text { survey }\end{array}$ & \begin{tabular}{|l} 
February 24, \\
2014
\end{tabular} & halfway through the concreting walls of the new lock head & 9 & 1005 & $9 \mathrm{SE}$ \\
\hline
\end{tabular}

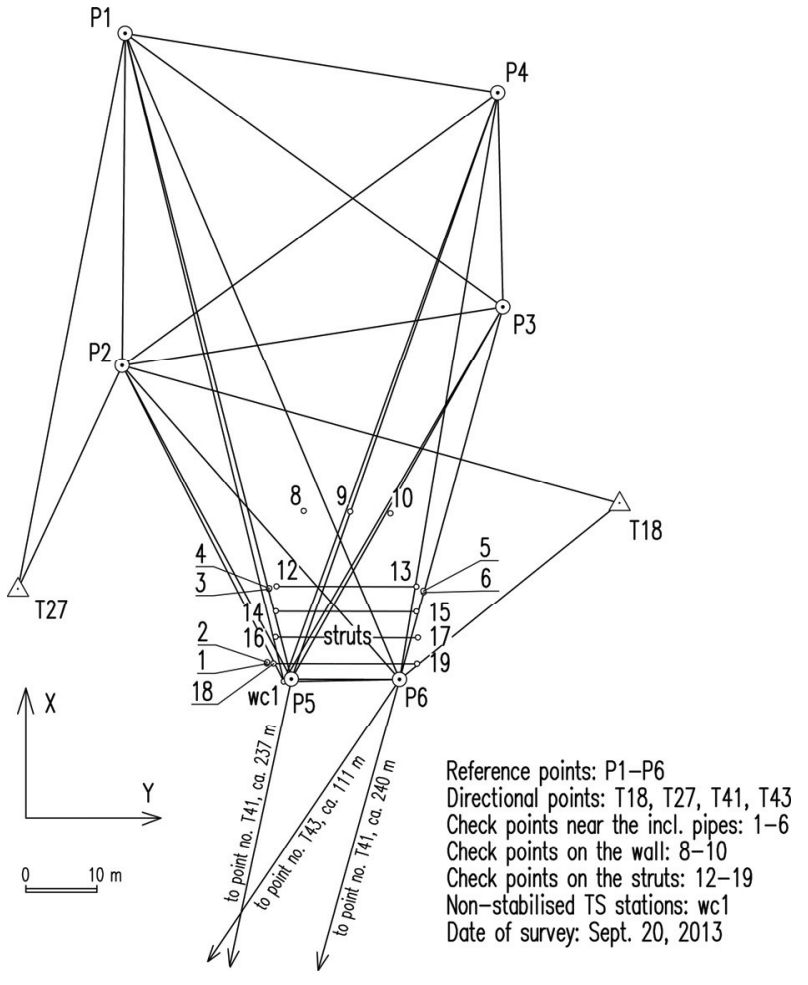

Fig. 3. Sketch of geodetic network with numbers of points - the 2nd check survey

total station) was performed using the so-called three tripods method (when all the tribrachs remain centred

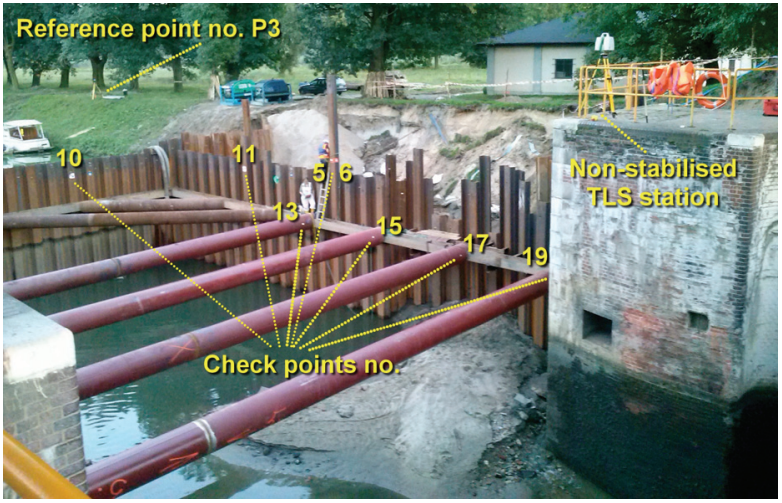

Fig. 4. Sketch of chosen points localisation - the 1 st check survey

on tripods, while a prism and the instrument are exchanged in all possible combinations). The check points were indicated with reflective sheet target.

Initially, measurements of check points were performed using stabilised reference points as instrument stations (P5 and P6). Later, when these stations were destroyed, the measurements were performed from non-stabilised stations, using the method of resection for reference points. All total station measurements were performed in at least two measurement sets, using the automatic targeting on points indicated by the prisms. Check points were manually targeted. Distance 
to all measured points were checked twice, with each targeting.

Measurements with terrestrial laser scanner (TLS) were usually performed using two or three stations. The nominal density of the scanning in the distance of $30.0 \mathrm{~m}$ was identical in both directions and equal to $18 \mathrm{~mm}$. The entire interior of the chamber was measured from every station, which ultimately enabled a higher density of measured points. Scanner stations were combined separately for each measurement period based on common points (targets). In each measurement, three scanner targets were used and placed in reference points, and three to five targets were temporarily stuck to the structure under scrutiny. Laser scanner measurements were performed only for first four campaign.

\section{PERFORMED TESTS AND ANALYSIS OF MEASUREMENT RESULTS}

For each measurement period, the results obtained from the total station were processed and preadjusted using the least squares method according to a general formula describing functional model (1) where: $V$ - vector of corrections, $A$ - matrix of coefficient, $h$ - vector of unknowns parameters, $L$ - vector of free terms, $P$ - weight matrix.

$$
V=A h-L, \quad P .
$$

Pre-adjustments were performed with constraint to the minimum number of reference points (one reference point and one direction). It made it possible to check the consistency of observational material and to prepare to the process of identifying fixed points of reference. This process was carried out using 2D Helmert transformation without changing the scale (the so-called search transformations). The general transformation error represents the matching quality between the "physical realization" of the reference system in each successive periodic measurement (after rejecting the unstable points) and the "physical realization" of the reference system from the initial measurement. For example, for the first three periodic measurements, the transformation errors were as follows: $0.6 \mathrm{~mm}, 1.0 \mathrm{~mm}$ and $1.5 \mathrm{~mm}$. After identifying the fixed reference points for each measurement period, the final angular-linear network adjustment was performed using the least squares method. The values of minimum, maximum and the average error of the horizontal position of the check points after the adjustment were juxtaposed in Table 2. A little lower accuracy obtained from the 3rd check survey was a result of difficult measuring conditions.

On the basis of the final coordinates (calculated from tacheometry observations) of the check points from each measurement periods, horizontal displace-

Table 2. The minimum, maximum and the average error of the horizontal position of the check points after adjustment

\begin{tabular}{|c|c|c|c|c|c|c|c|c|c|}
\hline \multirow{3}{*}{$\begin{array}{c}\text { 2D mean error } \\
{[\mathrm{mm}]}\end{array}$} & \multicolumn{9}{|c|}{ Survey } \\
\hline & \multirow{2}{*}{$\frac{\text { initial }}{0}$} & \multicolumn{8}{|c|}{ check } \\
\hline & & $1 \mathrm{st}$ & 2nd & $3 \mathrm{rd}$ & 4 th & 5 th & 6th & 7 th & 8th \\
\hline $\min$ & 0.5 & 0.5 & 0.4 & 1.1 & 0.8 & 0.8 & 0.8 & 0.9 & 0.8 \\
\hline $\max$ & 1.0 & 1.1 & 1.1 & 1.6 & 1.3 & 1.3 & 1.4 & 1.3 & 1.3 \\
\hline avg & 0.7 & 0.7 & 0.7 & 1.4 & 1.0 & 1.1 & 1.1 & 1.1 & 1.1 \\
\hline
\end{tabular}

Table 3. The horizontal displacements of the check points located near to inclinometric pipes and calculated on the basis of the total station measurements

\begin{tabular}{|c|c|c|c|c|c|c|c|c|}
\hline \multirow{2}{*}{$\begin{array}{c}\text { No. of } \\
\text { check point }\end{array}$} & \multicolumn{4}{|c|}{ 1st check survey } & \multicolumn{4}{c|}{ 2nd check survey } \\
\cline { 2 - 9 } & $\begin{array}{c}\Delta x \\
{[\mathrm{~mm}]}\end{array}$ & $\begin{array}{c}m \Delta x \\
{[\mathrm{~mm}]}\end{array}$ & $\begin{array}{c}\Delta y \\
{[\mathrm{~mm}]}\end{array}$ & $\begin{array}{c}m \Delta y \\
{[\mathrm{~mm}]}\end{array}$ & $\begin{array}{c}\Delta x \\
{[\mathrm{~mm}]}\end{array}$ & $\begin{array}{c}m \Delta x \\
{[\mathrm{~mm}]}\end{array}$ & $\begin{array}{c}\Delta y \\
{[\mathrm{~mm}]}\end{array}$ & $\begin{array}{c}m \Delta y \\
{[\mathrm{~mm}]}\end{array}$ \\
\hline 1 & -18.8 & 0.6 & 0.5 & 0.8 & -20.7 & 0.5 & 1.9 & 0.8 \\
\hline 2 & -19.5 & 0.4 & 2.2 & 0.7 & -21.7 & 0.4 & 4.6 & 0.7 \\
\hline 3 & -14.3 & 0.7 & 3.5 & 0.4 & -13.7 & 0.7 & 8.1 & 0.4 \\
\hline 4 & -12.1 & 0.9 & 0.4 & 0.5 & -11.4 & 0.9 & 3.8 & 0.5 \\
\hline 5 & -9.6 & 0.9 & 7.5 & 0.5 & -9.1 & 0.9 & 9.4 & 0.5 \\
\hline 6 & -10.6 & 0.7 & 5.6 & 0.5 & -10.8 & 0.7 & 4.7 & 0.4 \\
\hline
\end{tabular}




\begin{tabular}{|c|c|c|c|c|c|c|c|c|}
\hline \multirow{2}{*}{$\begin{array}{c}\text { No. of } \\
\text { check point }\end{array}$} & \multicolumn{4}{|c|}{ 3rd check survey } & \multicolumn{4}{|c|}{ 4th check survey } \\
\hline & $\begin{array}{c}\Delta x \\
{[\mathrm{~mm}]}\end{array}$ & $\begin{array}{c}m \Delta x \\
{[\mathrm{~mm}]}\end{array}$ & $\begin{array}{c}\Delta y \\
{[\mathrm{~mm}]}\end{array}$ & $\begin{array}{c}m \Delta y \\
{[\mathrm{~mm}]}\end{array}$ & $\begin{array}{c}\Delta x \\
{[\mathrm{~mm}]}\end{array}$ & $\begin{array}{c}m \Delta x \\
{[\mathrm{~mm}]}\end{array}$ & $\begin{array}{c}\Delta y \\
{[\mathrm{~mm}]}\end{array}$ & $\begin{array}{l}m \Delta y \\
{[\mathrm{~mm}]}\end{array}$ \\
\hline 1 & -23.7 & 0.8 & -3.6 & 1.5 & -27.4 & 0.7 & -2.7 & 1.3 \\
\hline 2 & -24.7 & 0.8 & 0.2 & 1.5 & -28.0 & 0.7 & -1.0 & 1.2 \\
\hline 3 & -17.8 & 0.9 & -6.2 & 0.9 & -23.8 & 0.8 & -32.3 & 0.7 \\
\hline 4 & -14.6 & 1.1 & -10.6 & 1.2 & -21.7 & 0.8 & -34.9 & 0.8 \\
\hline 5 & -15.2 & 1.1 & -6.2 & 0.9 & -24.7 & 1.0 & -23.6 & 1.0 \\
\hline 6 & -16.8 & 0.9 & -11.7 & 0.9 & -26.1 & 0.8 & -26.1 & 0.7 \\
\hline \multirow{2}{*}{$\begin{array}{c}\text { No. of } \\
\text { check point }\end{array}$} & \multicolumn{4}{|c|}{5 th check survey } & \multicolumn{4}{|c|}{ 6th check survey } \\
\hline & $\begin{array}{c}\Delta x \\
{[\mathrm{~mm}]}\end{array}$ & $\begin{array}{c}m \Delta x \\
{[\mathrm{~mm}]}\end{array}$ & $\begin{array}{c}\Delta y \\
{[\mathrm{~mm}]}\end{array}$ & $\begin{array}{c}m \Delta y \\
{[\mathrm{~mm}]}\end{array}$ & $\begin{array}{c}\Delta x \\
{[\mathrm{~mm}]}\end{array}$ & $\begin{array}{l}m \Delta x \\
{[\mathrm{~mm}]}\end{array}$ & $\begin{array}{c}\Delta y \\
{[\mathrm{~mm}]}\end{array}$ & $\begin{array}{c}m \Delta y \\
{[\mathrm{~mm}]}\end{array}$ \\
\hline 1 & -28.2 & 0.9 & 2.6 & 1.1 & -29.3 & 1.1 & -10.8 & 1.1 \\
\hline 2 & -28.1 & 0.9 & 2.4 & 1.0 & -28.9 & 0.7 & -11.4 & 0.9 \\
\hline 3 & -27.7 & 0.8 & -42.1 & 0.6 & -26.9 & 0.8 & -40.9 & 0.7 \\
\hline 4 & -25.4 & 0.8 & -43.9 & 0.7 & -26.2 & 0.9 & -40.6 & 0.7 \\
\hline 5 & -30.0 & 0.9 & -24.3 & 0.9 & -31.8 & 1.1 & -22.3 & 1.1 \\
\hline 6 & -30.9 & 0.9 & -24.9 & 0.9 & -31.9 & 0.9 & -22.9 & 0.7 \\
\hline \multirow{2}{*}{$\begin{array}{c}\text { No. of } \\
\text { check point }\end{array}$} & \multicolumn{4}{|c|}{7 th check survey } & \multicolumn{4}{|c|}{8 th check survey } \\
\hline & $\begin{array}{c}\Delta x \\
{[\mathrm{~mm}]}\end{array}$ & $\begin{array}{l}m \Delta x \\
{[\mathrm{~mm}]}\end{array}$ & $\begin{array}{c}\Delta y \\
{[\mathrm{~mm}]}\end{array}$ & $\begin{array}{c}m \Delta y \\
{[\mathrm{~mm}]}\end{array}$ & $\begin{array}{c}\Delta x \\
{[\mathrm{~mm}]}\end{array}$ & $\begin{array}{c}m \Delta x \\
{[\mathrm{~mm}]}\end{array}$ & $\begin{array}{c}\Delta y \\
{[\mathrm{~mm}]}\end{array}$ & $\begin{array}{c}m \Delta y \\
{[\mathrm{~mm}]}\end{array}$ \\
\hline $1 \mathrm{a}$ & n.a. & n.a. & n.a. & n.a. & $0.4^{*}$ & $1.0^{*}$ & $4.6^{*}$ & $1.1^{*}$ \\
\hline $2 \mathrm{a}$ & n.a. & n.a. & n.a. & n.a. & $0.7^{*}$ & $1.1^{*}$ & $4.2^{*}$ & $1.1^{*}$ \\
\hline 3 & -29.8 & 0.8 & -42.7 & 0.8 & -30.6 & 1.1 & -39.6 & 0.8 \\
\hline $4 a$ & n.a. & n.a. & n.a. & n.a. & $0.7^{*}$ & $1.1^{*}$ & $4.5^{*}$ & $1.5^{*}$ \\
\hline $5 \mathrm{a}$ & $\mathrm{n} / \mathrm{a}$ & n.a. & n.a. & n.a. & $0.3^{*}$ & $1.1^{*}$ & $-4.0^{*}$ & $1.4^{*}$ \\
\hline $6 a$ & $\mathrm{n} / \mathrm{a}$ & n.a. & n.a. & n.a. & $0.2^{*}$ & $1.0^{*}$ & $-5.0 *$ & $1.2^{*}$ \\
\hline
\end{tabular}

* - the values of displacements and the mean errors for new check points (marked by suffix "a") calculated with respect to 7 th check survey treated as the initial survey.

n.a. - not available.

ment values were calculated. Table 3 presents horizontal displacements for check points located near inclinometric pipes (points no. 1-6). Table 4 presents horizontal displacements for check points located on the struts (points no. 12-19). Table 5 presents hori- zontal displacements for check points located on the sheet pile wall (points no. 8-11). During the construction work some check points were damaged and then re-stabilized. Those points have number with suffix "a".

Table 4. The horizontal displacements of the check points located on the struts and calculated on the basis of the total station measurements

\begin{tabular}{|c|c|c|c|c|c|c|c|c|}
\hline \multirow{2}{*}{$\begin{array}{c}\text { No. of } \\
\text { check point }\end{array}$} & \multicolumn{4}{|c|}{ 1st check survey } & \multicolumn{4}{|c|}{ 2nd check survey } \\
\hline & $\begin{array}{c}\Delta x \\
{[\mathrm{~mm}]}\end{array}$ & $\begin{array}{c}m \Delta x \\
{[\mathrm{~mm}]}\end{array}$ & $\begin{array}{c}\Delta y \\
{[\mathrm{~mm}]}\end{array}$ & $\begin{array}{c}m \Delta y \\
{[\mathrm{~mm}]}\end{array}$ & $\begin{array}{c}\Delta x \\
{[\mathrm{~mm}]}\end{array}$ & $\begin{array}{l}m \Delta x \\
{[\mathrm{~mm}]}\end{array}$ & $\begin{array}{c}\Delta y \\
{[\mathrm{~mm}]}\end{array}$ & $\begin{array}{c}m \Delta y \\
{[\mathrm{~mm}]}\end{array}$ \\
\hline 12 & -17.1 & 0.7 & 2.9 & 0.4 & -20.3 & 0.7 & 5.5 & 0.4 \\
\hline 13 & -10.6 & 0.7 & 3.4 & 0.5 & -15.3 & 0.7 & 4.1 & 0.4 \\
\hline 14 & -18.2 & 0.7 & 2.8 & 0.4 & -20.8 & 0.6 & 5.3 & 0.3 \\
\hline 15 & -11.9 & 0.7 & 1.7 & 0.4 & -16.6 & 0.7 & 2.2 & 0.4 \\
\hline 16 & -17.2 & 0.6 & -0.4 & 0.9 & -19.6 & 0.6 & 1.7 & 0.9 \\
\hline 17 & -12.0 & 0.6 & 2.0 & 0.4 & -16.7 & 0.6 & 2.4 & 0.3 \\
\hline 18 & -18.7 & 0.6 & 3.0 & 1.3 & -20.2 & 0.6 & 5.5 & 1.3 \\
\hline 19 & -11.9 & 0.6 & 2.4 & 1.3 & -16.4 & 0.5 & 0.2 & 1.1 \\
\hline
\end{tabular}




\begin{tabular}{|c|c|c|c|c|c|c|c|c|}
\hline \multirow{2}{*}{$\begin{array}{c}\text { No. of } \\
\text { check point }\end{array}$} & \multicolumn{4}{|c|}{ 3rd check survey } & \multicolumn{4}{|c|}{ 4th check survey } \\
\hline & $\begin{array}{c}\Delta x \\
{[\mathrm{~mm}]}\end{array}$ & $\begin{array}{l}m \Delta x \\
{[\mathrm{~mm}]}\end{array}$ & $\begin{array}{c}\Delta y \\
{[\mathrm{~mm}]}\end{array}$ & $\begin{array}{c}m \Delta y \\
{[\mathrm{~mm}]}\end{array}$ & $\begin{array}{c}\Delta x \\
{[\mathrm{~mm}]}\end{array}$ & $\begin{array}{l}m \Delta x \\
{[\mathrm{~mm}]}\end{array}$ & $\begin{array}{c}\Delta y \\
{[\mathrm{~mm}]}\end{array}$ & $\begin{array}{c}m \Delta y \\
{[\mathrm{~mm}]}\end{array}$ \\
\hline 12 & -23.0 & 0.9 & -4.9 & 0.9 & -27.1 & 0.8 & -17.1 & 0.7 \\
\hline 13 & -23.7 & 0.9 & -8.2 & 0.9 & -28.1 & 0.8 & -21.7 & 0.7 \\
\hline 14 & -23.1 & 0.9 & -4.7 & 0.9 & -25.5 & 0.7 & -15.7 & 0.6 \\
\hline 15 & -24.4 & 0.9 & -9.1 & 0.9 & -29.3 & 0.7 & -21.4 & 0.7 \\
\hline 16 & -21.5 & 0.9 & -5.2 & 1.6 & -22.9 & 0.7 & -13.5 & 1.2 \\
\hline 17 & -24.5 & 0.9 & -5.1 & 1.3 & -29.2 & 0.7 & -14.8 & 0.6 \\
\hline 18 & -21.9 & 0.8 & 1.4 & 1.7 & -23.3 & 0.6 & 0.2 & 1.4 \\
\hline 19 & -24.4 & 0.7 & -4.2 & 1.5 & -27.6 & 0.7 & -6.6 & 1.4 \\
\hline \multirow{2}{*}{$\begin{array}{c}\text { No. of } \\
\text { check point }\end{array}$} & \multicolumn{4}{|c|}{ 5th check survey } & \multicolumn{4}{|c|}{ 6th check survey } \\
\hline & $\begin{array}{c}\Delta x \\
{[\mathrm{~mm}]}\end{array}$ & $\begin{array}{l}m \Delta x \\
{[\mathrm{~mm}]}\end{array}$ & $\begin{array}{c}\Delta y \\
{[\mathrm{~mm}]}\end{array}$ & $\begin{array}{c}m \Delta y \\
{[\mathrm{~mm}]}\end{array}$ & $\begin{array}{c}\Delta x \\
{[\mathrm{~mm}]}\end{array}$ & $\begin{array}{l}m \Delta x \\
{[\mathrm{~mm}]}\end{array}$ & $\begin{array}{c}\Delta y \\
{[\mathrm{~mm}]}\end{array}$ & $\begin{array}{c}m \Delta y \\
{[\mathrm{~mm}]}\end{array}$ \\
\hline 12 & -26.5 & 1.1 & -19.4 & 0.7 & -26.9 & 0.9 & -24.5 & 0.7 \\
\hline 13 & -27.7 & 0.9 & -22.8 & 0.9 & -29.1 & 0.9 & -29.3 & 0.7 \\
\hline 14 & -26.6 & 0.8 & -15.7 & 0.6 & -28.5 & 1.3 & -21.5 & 0.6 \\
\hline 15 & -29.2 & 0.8 & -21.0 & 0.9 & -30.3 & 0.9 & -27.6 & 0.7 \\
\hline 16 & -23.9 & 0.8 & -12.1 & 1.1 & -23.4 & 1.2 & -16.8 & 1.1 \\
\hline 17 & -29.2 & 0.6 & -12.9 & 0.8 & -29.9 & 0.7 & -19.0 & 0.6 \\
\hline 18 & -24.4 & 0.6 & 2.3 & 1.3 & -23.0 & 0.7 & -0.9 & 1.5 \\
\hline 19 & -27.9 & 0.6 & -5.3 & 1.2 & -28.7 & 0.6 & -9.6 & 1.3 \\
\hline \multirow{2}{*}{$\begin{array}{c}\text { No. of check } \\
\text { point }\end{array}$} & \multicolumn{4}{|c|}{ 7th check survey } & \multicolumn{4}{|c|}{ 8th check survey } \\
\hline & $\begin{array}{c}\Delta x \\
{[\mathrm{~mm}]}\end{array}$ & $\begin{array}{l}m \Delta x \\
{[\mathrm{~mm}]}\end{array}$ & $\begin{array}{c}\Delta y \\
{[\mathrm{~mm}]}\end{array}$ & $\begin{array}{c}m \Delta y \\
{[\mathrm{~mm}]}\end{array}$ & $\begin{array}{c}\Delta x \\
{[\mathrm{~mm}]}\end{array}$ & $\begin{array}{l}m \Delta x \\
{[\mathrm{~mm}]}\end{array}$ & $\begin{array}{c}\Delta y \\
{[\mathrm{~mm}]}\end{array}$ & $\begin{array}{c}m \Delta y \\
{[\mathrm{~mm}]}\end{array}$ \\
\hline 12 & -28.8 & 0.8 & -26.1 & 0.8 & n.a. & n.a. & n.a. & n.a. \\
\hline 13 & -32.1 & 1.1 & -32.0 & 0.8 & n.a. & n.a. & n.a. & n.a. \\
\hline 14 & -27.4 & 0.8 & -23.1 & 0.7 & n.a. & n.a. & n.a. & n.a. \\
\hline 15 & -32.4 & 1.1 & -29.8 & 0.8 & n.a. & n.a. & n.a. & n.a. \\
\hline 16 & -24.8 & 0.8 & -17.8 & 1.1 & n.a. & n.a. & n.a. & n.a. \\
\hline 17 & -33.5 & 1.1 & -20.8 & 0.7 & n.a. & n.a. & n.a. & n.a. \\
\hline 18 & -25.5 & 0.7 & -2.8 & 1.5 & n.a. & n.a. & n.a. & n.a. \\
\hline 19 & -31.2 & 0.7 & -10.2 & 1.5 & n.a. & n.a. & n.a. & n.a. \\
\hline
\end{tabular}

n.a. - not available.

Table 5. The horizontal displacements of the check points located on the cofferdam wall and calculated on the basis of the total station measurements

\begin{tabular}{|c|c|c|c|c|c|c|c|c|}
\hline \multirow{2}{*}{$\begin{array}{c}\text { No. of } \\
\text { check point }\end{array}$} & \multicolumn{4}{|c|}{ 1st check survey } & \multicolumn{4}{|c|}{ 2nd check survey } \\
\hline & $\begin{array}{c}\Delta x \\
{[\mathrm{~mm}]}\end{array}$ & $\begin{array}{c}m \Delta x \\
{[\mathrm{~mm}]}\end{array}$ & $\begin{array}{c}\Delta y \\
{[\mathrm{~mm}]}\end{array}$ & $\begin{array}{c}m \Delta y \\
{[\mathrm{~mm}]}\end{array}$ & $\begin{array}{c}\Delta x \\
{[\mathrm{~mm}]}\end{array}$ & $\begin{array}{c}m \Delta x \\
{[\mathrm{~mm}]}\end{array}$ & $\begin{array}{c}\Delta y \\
{[\mathrm{~mm}]}\end{array}$ & $\begin{array}{c}m \Delta y \\
{[\mathrm{~mm}]}\end{array}$ \\
\hline 8 & -18.2 & 0.9 & 0.6 & 0.6 & -24.9 & 0.9 & 3.3 & 0.6 \\
\hline 9 & -16.1 & 0.8 & 0.3 & 0.6 & -22.7 & 0.8 & 1.5 & 0.6 \\
\hline 10 & -24.1 & 0.9 & 1.6 & 0.6 & -29.9 & 0.9 & 0.1 & 0.6 \\
\hline 11 & -10.0 & 1.1 & 12.5 & 0.6 & n.a. & n.a. & n.a. & n.a. \\
\hline \multirow{2}{*}{$\begin{array}{c}\text { No. of } \\
\text { check point }\end{array}$} & \multicolumn{4}{|c|}{ 3rd check survey } & \multicolumn{4}{|c|}{ 4th check survey } \\
\hline & $\begin{array}{c}\Delta x \\
{[\mathrm{~mm}]}\end{array}$ & $\begin{array}{c}m \Delta x \\
{[\mathrm{~mm}]}\end{array}$ & $\begin{array}{c}\Delta y \\
{[\mathrm{~mm}]}\end{array}$ & $\begin{array}{c}m \Delta y \\
{[\mathrm{~mm}]}\end{array}$ & $\begin{array}{c}\Delta x \\
{[\mathrm{~mm}]}\end{array}$ & $\begin{array}{c}m \Delta x \\
{[\mathrm{~mm}]}\end{array}$ & $\begin{array}{c}\Delta y \\
{[\mathrm{~mm}]}\end{array}$ & $\begin{array}{c}m \Delta y \\
{[\mathrm{~mm}]}\end{array}$ \\
\hline $8 \mathrm{a}$ & $-20.2^{*}$ & $1.1 *$ & $-7.9 *$ & $0.9^{*}$ & $-23.7 *$ & $0.9^{*}$ & $-16.0^{*}$ & $0.8^{*}$ \\
\hline $9 \mathrm{a}$ & $-3.5^{*}$ & $1.0^{*}$ & $-9.4^{*}$ & $0.9^{*}$ & $-6.0^{*}$ & $0.9^{*}$ & $-20.6^{*}$ & $0.7^{*}$ \\
\hline $10 \mathrm{a}$ & $-3.7 *$ & $1.1 *$ & $-8.0 *$ & $1.0 *$ & $-3.8^{*}$ & $0.9 *$ & $-19.8^{*}$ & $0.8^{*}$ \\
\hline
\end{tabular}




\begin{tabular}{|c|c|c|c|c|c|c|c|c|}
\hline \multirow[b]{2}{*}{$\begin{array}{c}\text { No. of } \\
\text { check point }\end{array}$} & \multicolumn{4}{|c|}{ 5th check survey } & \multicolumn{4}{|c|}{ 6th check survey } \\
\hline & $\begin{array}{c}\Delta x \\
{[\mathrm{~mm}]}\end{array}$ & $\begin{array}{l}m \Delta x \\
{[\mathrm{~mm}]}\end{array}$ & $\begin{array}{c}\Delta y \\
{[\mathrm{~mm}]}\end{array}$ & $\begin{array}{c}m \Delta y \\
{[\mathrm{~mm}]}\end{array}$ & $\begin{array}{c}\Delta x \\
{[\mathrm{~mm}]}\end{array}$ & $\begin{array}{l}m \Delta x \\
{[\mathrm{~mm}]}\end{array}$ & $\begin{array}{c}\Delta y \\
{[\mathrm{~mm}]}\end{array}$ & $\begin{array}{c}m \Delta y \\
{[\mathrm{~mm}]}\end{array}$ \\
\hline $8 \mathrm{a}$ & $-22.9^{*}$ & $1.2^{*}$ & $-18.1 *$ & $0.9^{*}$ & $-28.8^{*}$ & $1.1^{*}$ & $-21.4^{*}$ & $0.9^{*}$ \\
\hline $9 \mathrm{a}$ & $-4.8^{*}$ & $1.2^{*}$ & $-23.4 *$ & $0.9^{*}$ & $-3.2 *$ & $1.0^{*}$ & $-28.2^{*}$ & $0.7^{*}$ \\
\hline $10 \mathrm{a}$ & $-4.2 *$ & $1.2 *$ & $-23.2 *$ & $0.9^{*}$ & $-2.6^{*}$ & $1.1^{*}$ & $-26.4 *$ & $0.8^{*}$ \\
\hline \multirow{2}{*}{$\begin{array}{c}\text { No. of } \\
\text { check point }\end{array}$} & \multicolumn{4}{|c|}{ 7th check survey } & \multicolumn{4}{|c|}{8 th check survey } \\
\hline & $\begin{array}{c}\Delta x \\
{[\mathrm{~mm}]}\end{array}$ & $\begin{array}{l}m \Delta \Delta x \\
{[\mathrm{~mm}]}\end{array}$ & $\begin{array}{c}\Delta y \\
{[\mathrm{~mm}]}\end{array}$ & $\begin{array}{c}m \Delta y \\
{[\mathrm{~mm}]}\end{array}$ & $\begin{array}{c}\Delta x \\
{[\mathrm{~mm}]}\end{array}$ & $\begin{array}{l}m \Delta x \\
{[\mathrm{~mm}]}\end{array}$ & $\begin{array}{c}\Delta y \\
{[\mathrm{~mm}]}\end{array}$ & $\begin{array}{c}m \Delta \Delta y \\
{[\mathrm{~mm}]}\end{array}$ \\
\hline $8 \mathrm{a}$ & $-32.7 *$ & $1.0^{*}$ & $-22.3^{*}$ & $0.9^{*}$ & $-86.4^{*}$ & $0.9 *$ & $-24.4^{*}$ & $0.7^{*}$ \\
\hline $9 a$ & $-5.3^{*}$ & $0.9^{*}$ & $-29.6 *$ & $0.8^{*}$ & $-98.3^{*}$ & $0.9^{*}$ & $-29.7 *$ & $0.7^{*}$ \\
\hline $10 \mathrm{a}$ & $-5.5^{*}$ & $1.0 *$ & $-28.1^{*}$ & $0.9^{*}$ & $-58.7 *$ & $1.0^{*}$ & $-30.3^{*}$ & $0.9^{*}$ \\
\hline
\end{tabular}

* - the values of displacements and the mean errors for new check points (marked by suffix 'a') calculated with respect to 2 th check survey treated as the initial survey.

n.a. - not available.

Preparation of data obtained from terrestrial laser scanning consisted in pre-treatment of clouds of points (including the purification of point cloud). Then, combination of various scanner stations (the socalled clouds registration) were performed, separately for each measurement period. Point clouds were combined within the local coordinate system of the selected scanner station (the so-called free registration), based on the common targets. Next, the appropriate georeference was given to be able to compare the results from the total station and from the scanner. This step a is so-called nested registration and depends on transforming the combined clouds to the coordinate system of the total station (represented by three scanner targets, located on the reference points with known coordinates). The accuracy of both registrations (the free and the nested one) is presented in Table 6.

Table 6. Mean absolute error of subsequent registration [mm]

\begin{tabular}{|l|c|c|c|c|}
\hline \multicolumn{1}{|c|}{ Measurement } & Initial & 1st check & 2nd check & 3rd check \\
\hline Free registration & 2 & 1 & 1 & 1 \\
\hline Nested registration & 2 & 3 & 2 & 1 \\
\hline
\end{tabular}

To be able to compare the displacement values of the cofferdam in chosen points using data from the scanner, the scanner targets should have been permanently stuck in this points. Unfortunately, the appropriate targets stuck during the initial measurement were soon damaged. The only solution was to model some parts of struts construction on the basis of point clouds (Fig. 5a). The $X$ axis of coordinate system was approximately parallel to the frame of sheet pile wall. For determining horizontal displacements in $Y$ direction, some chosen parts of the upper frame were modelled (Fig. 5b) by fitting (by means of the least squares method) a planar patch in selected group of points near the check points (from $0.5 \mathrm{~m}$ to $0.9 \mathrm{~m}$ ). The $Y$ axis of coordinate system was approximately parallel to the struts. For determining horizontal displacements in $X$ direction some chosen parts of the steel pipes were modelled (Fig. 5b) by fitting (using the least squares method) a strip of cylinder with a width of $5 \mathrm{~cm}$. For each check point, the changes in location of the cylinder centre in different measurement periods were considered as the displacement in the direction of the $X$ axis. Similarly, the changes in location of the plane along the $Y$ axis were taken as the displacements

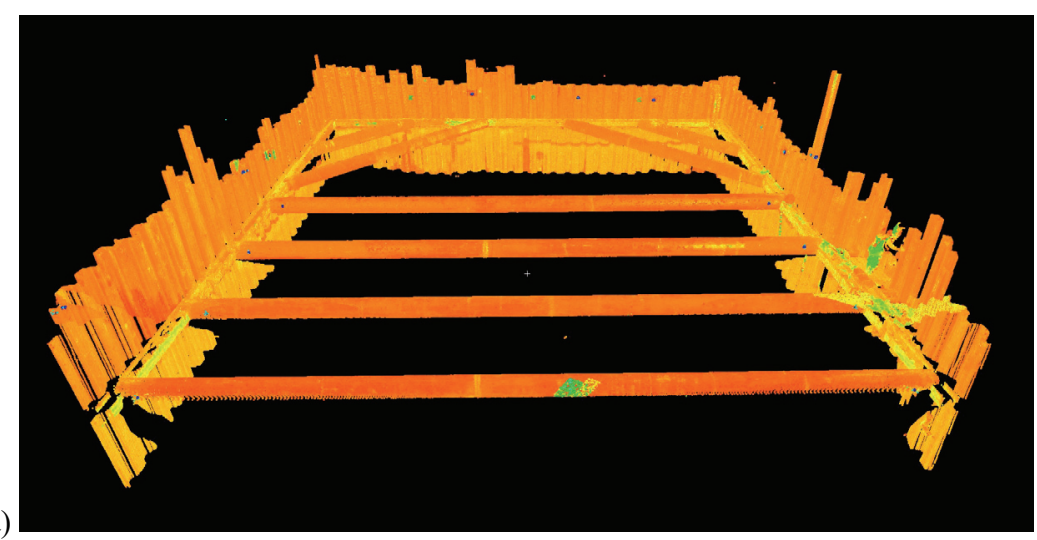

Fig. 5. The view of the point cloud from the 1st check survey (a) and the idea of point cloud modelling (b)

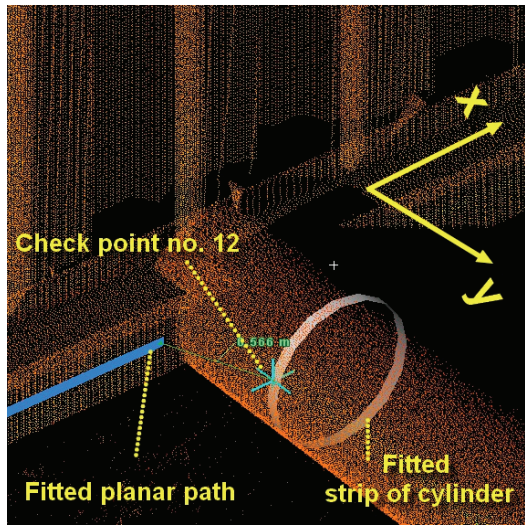

) 
in this direction. The values of horizontal displacements on the basis of the terrestrial laser scanning measurements are juxtaposed in Table 7. According to the technical specification of the scanner, the accuracy of fitting the theoretical model into the point cloud is about $\pm 2 \mathrm{~mm}$ in good conditions. Thus, the accuracy of the displacement determination can be estimated as $\pm 3 \mathrm{~mm}$ for each coordinate.

At this stage it is possible to calculate deviations between the values of horizontal displacements ob-

Table 7. The values of horizontal displacements of strut's ends on the basis of the terrestrial laser scanning measurements

\begin{tabular}{|c|c|c|c|c|c|c|}
\hline \multirow{2}{*}{$\begin{array}{c}\text { Vicinity } \\
\text { of check points } \\
\text { number }\end{array}$} & \multicolumn{2}{|c|}{ 1st check survey } & \multicolumn{2}{c|}{ 2nd check survey } & \multicolumn{2}{c|}{ 3rd check survey } \\
\cline { 2 - 7 } & \multicolumn{2}{|c|}{ displacements [mm] } & \multicolumn{2}{c|}{ displacements [mm] } & \multicolumn{2}{c|}{ displacements [mm] } \\
\cline { 2 - 7 } & $\Delta X$ & $\Delta Y$ & $\Delta X$ & $\Delta Y$ & $\Delta X$ & $\Delta Y$ \\
\hline 12 & -18.9 & 4.4 & -22.1 & 4.4 & -25.2 & -5.8 \\
\hline 13 & -13.7 & 5.3 & -18.1 & 4.5 & -27.4 & -5.1 \\
\hline 14 & -18.9 & 3.5 & -22.0 & 3.5 & -24.0 & -6.2 \\
\hline 15 & -10.8 & 3.5 & -15.0 & 2.7 & -23.8 & -6.4 \\
\hline 16 & -17.3 & 4.1 & -20.6 & 3.8 & -24.3 & -2.7 \\
\hline 17 & -12.4 & 3.3 & -14.1 & 1.6 & -26.5 & -3.0 \\
\hline 18 & -19.0 & 4.8 & -20.7 & 4.8 & -25.2 & 1.1 \\
\hline 19 & -11.7 & 4.6 & -14.2 & 2.6 & -26.9 & -0.1 \\
\hline
\end{tabular}

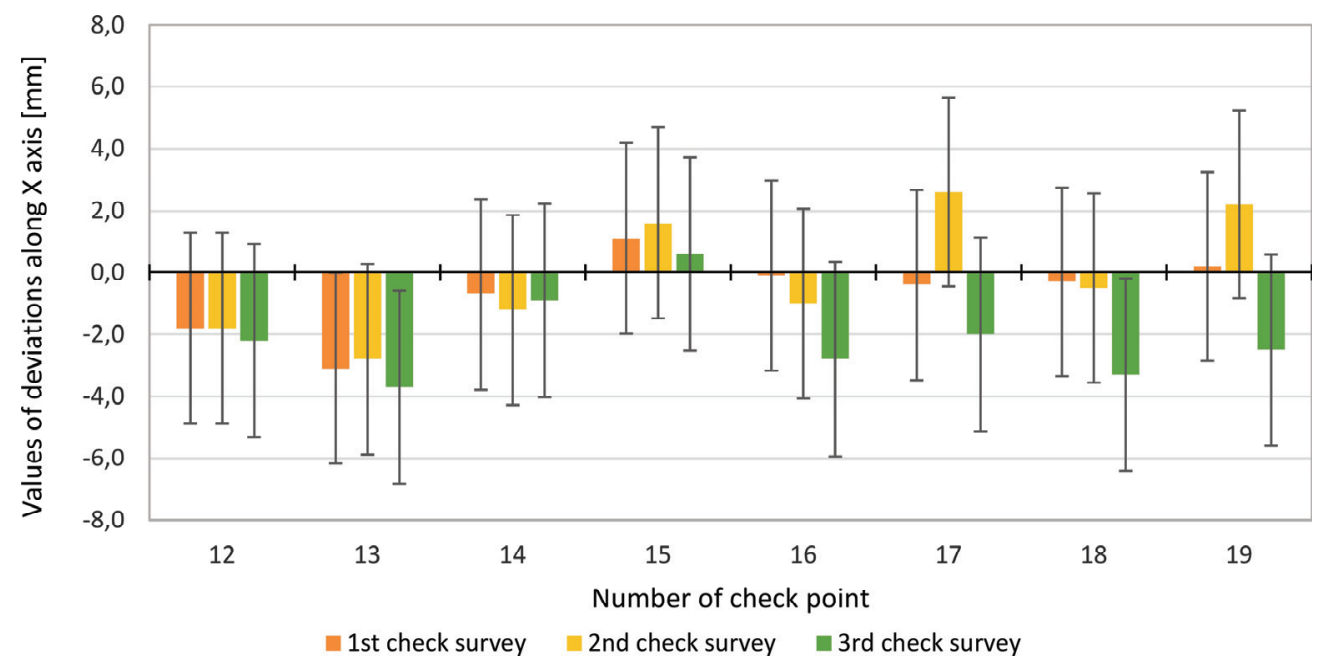

Fig. 6. Deviations of horizontal displacement values along $X$ axis

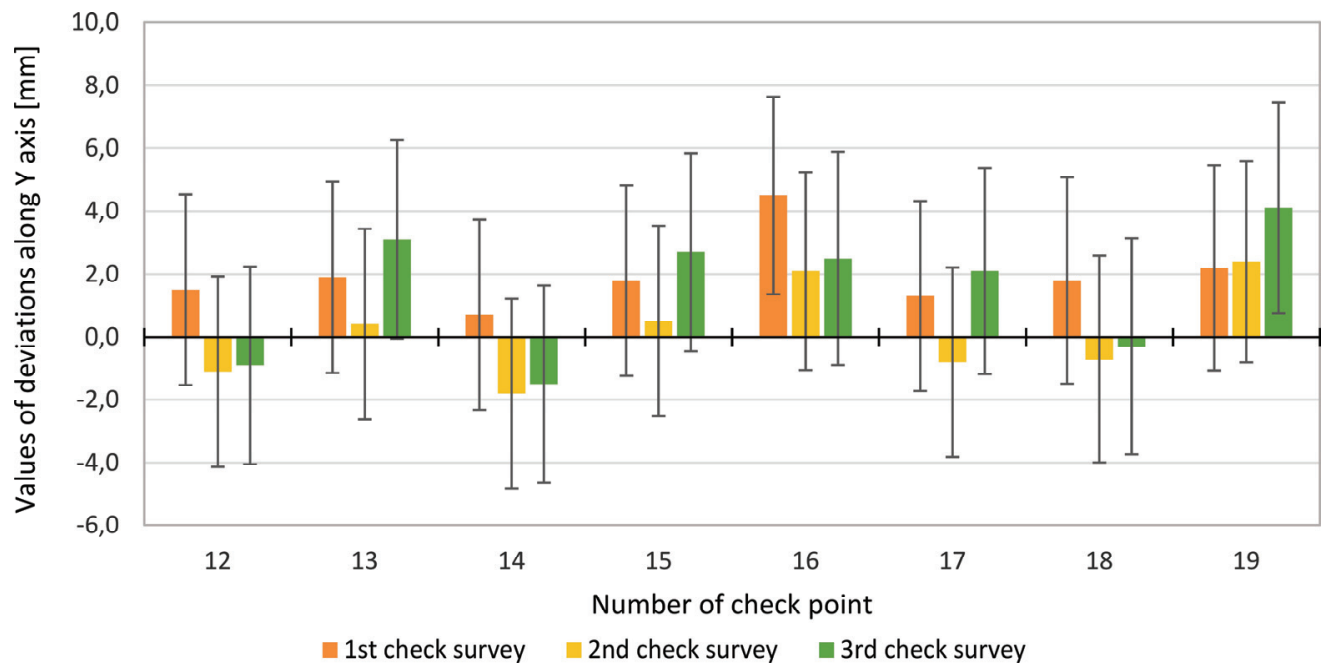

Fig. 7. Deviations of horizontal displacement values along $Y$ axis 
tained from modelling of point clouds and calculated from the total station measurements. These deviations (with mean errors) are presented separately for $X$ and $Y$ axes in Figs. 6 and 7.

Horizontal displacement values calculated based on total station measurements can be regarded as more reliable, although they were made with unfavourable angles of the laser beam reflection in reflectorless mode. The accuracy of the point cloud model depends not only on the scanner's noise but also on the "regularity" of the modelled shape. Additionally, the modelled plane is lo- cated at some distance from check point, and the value of displacement is also affected by the vulnerability of the connection between frame and strut. However, the deviations of displacement components are rather small and do not exceed $\pm 4 \mathrm{~mm}$ along the $X$ axis and $\pm 5 \mathrm{~mm}$ along the $Y$ axis. The significant part of the deviation values $(87 \%)$ is within $\pm 3 \mathrm{~mm}$.

Another way to use point clouds from two measuring epochs is to directly compare them and calculate the absolute distances between points from both epochs. These distances cannot be considered as displacement,

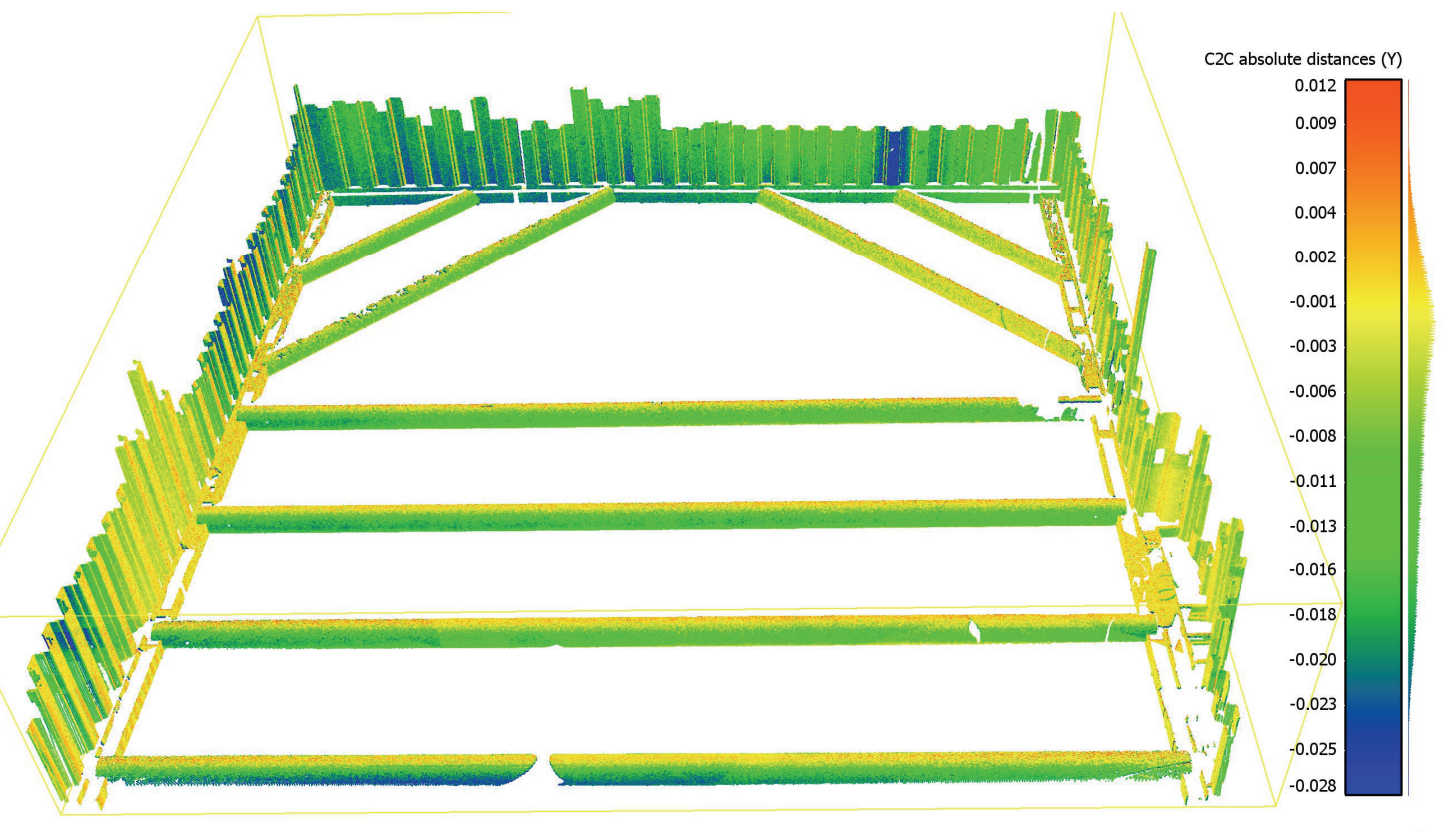

Fig. 8. Absolute distances along $X$ axis $[\mathrm{mm}]$ between initial and 1st check survey (calculated method: cloud to cloud)

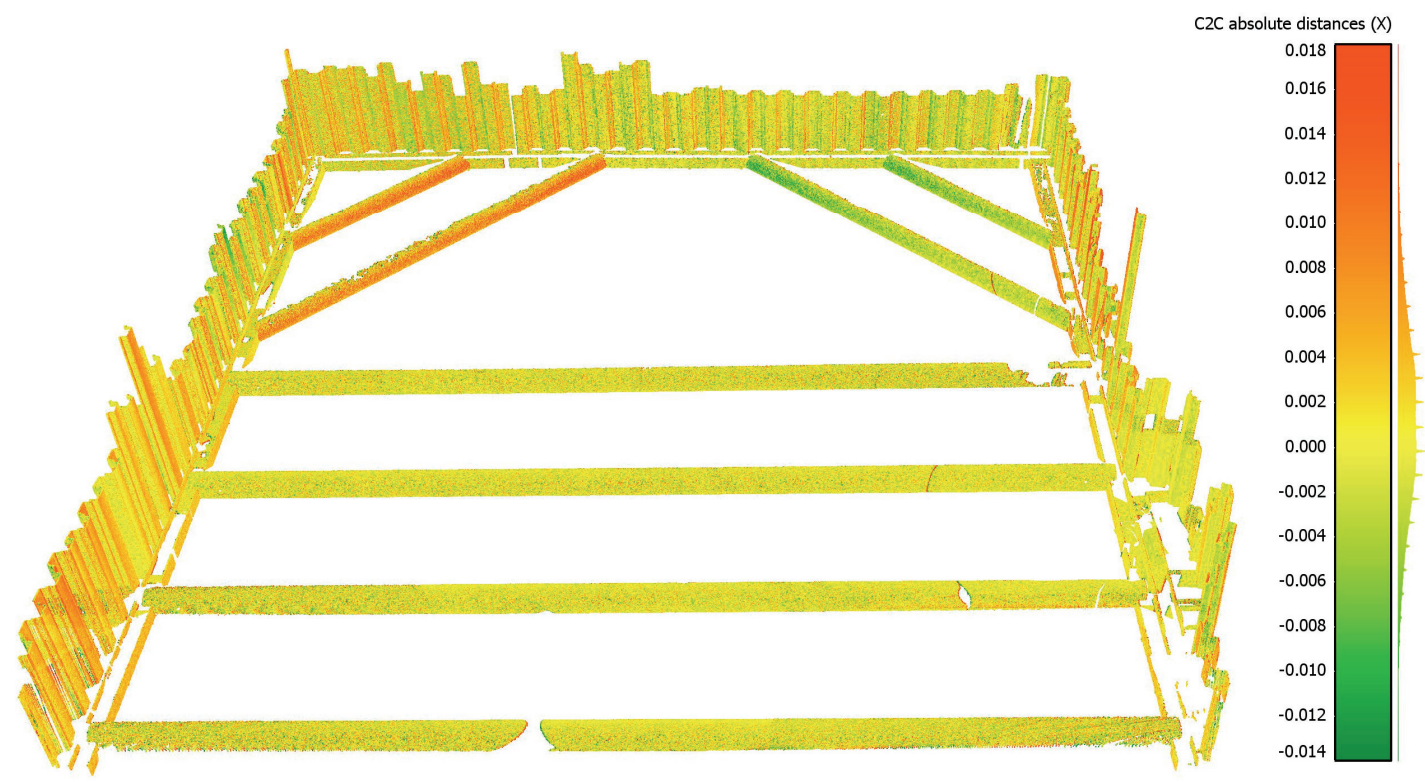

Fig. 9. Absolute distances along $Y$ axis $[\mathrm{mm}]$ between initial and 1st check survey (calculated method: cloud to cloud) 
but indicate a change in the shape and/or position of the structure elements. The results of such comparison between the point cloud from the initial survey and the 1st check survey are presented in Figs. 8 and 9. The reliability of the obtained results depends largely on the quality of the two cloud points. Similar density of points in the clouds, lack of empty areas and lack of disruptions and covers are very desirable.

\section{CONCLUSIONS}

The results of the study confirm that terrestrial laser scanning can be used successfully to determine horizontal displacements of hydrotechnical structures. Even under unfavourable distribution of instrument stations in terms of geometry, which usually occurs in hydraulic engineering facilities, it is possible to obtain the accuracy of cloud's registration at the level of individual millimetres. It is recommended to make a registration based only on geodetic points with known coordinates which were determined by means of precise total station's measurements. When the number of these points is too small to directly register every station of the scanner, the tie points with local coordinates or even characteristic points on the structure can be used. Then the second registration is necessary to reach the desired coordinate system. Using a two-steps clouds' registration, greater control over the accuracy of this process can be obtained, which enables checking the possible systematic errors of measurements made then using the scanner.

The value of deviations in components of horizontal displacements between the results obtained from the scanner and from the total station (from initial to 3 rd check survey) do not exceed $\pm 5 \mathrm{~mm}$. It should be noted that for the first four measurement campaigns, the environmental conditions prevailing during the measurement were very similar. The obtained results are comparable to the author's previous research on the modelling of planes around inclinometer pipes on the same hydrotechnical object [9]. Precise tacheometry ensures higher accuracy, however the above-mentioned $\pm 5 \mathrm{~mm}$ is a relatively small value compared to the absolute values of displacements reaching up to $33 \mathrm{~mm}$ (for the 7th check survey).

The biggest advantage of using terrestrial laser scanning is the possibility of receiving the geometry of the whole cofferdam surface. Comparing two point clouds from different time periods, the changes of the object shape and the "displacements" can be determined if the same reference system is kept for both point clouds. The absolute distances (calculated by means of "cloud to cloud" method in CloudCompare software) give generally comparable results with displacement components from tacheometry. Considering the horizontal displacements along the $X$ axis for 1st check measurement, the right side of the struts on Fig. 8 is marked in light green (about $-12 \mathrm{~mm}$ on the scale bar) and the left side has a colour between green and blue (about $-20 \mathrm{~mm}$ on the scale bar). These values are similar to the results of classical measurements. The check points with an odd numbers located on the right ends of struts (Fig. 3) have $X$ component of displacements ranging from $-10.6 \mathrm{~mm}$ to $-12.0 \mathrm{~mm}$ ). The check points on the left ends of the struts (evennumbered) have $X$ component of displacements ranging from $-17.1 \mathrm{~mm}$ to $-18.7 \mathrm{~mm}$. Considering the horizontal displacements along $\mathrm{Y}$ axis for the same measurement period, both ends of the struts marked yellow or orange, which corresponds to the values of absolute distances between 0 and $2 \mathrm{~mm}$. The same component calculated from the tacheometry for check points no. $12-19$ has a values from $-0.4 \mathrm{~mm}$ to $3.4 \mathrm{~mm}$. Analogical compatibility can be found for control points located near inclinometer pipes (Table 3) and located on the front wall of cofferdam (Table 5) compared to the results shown in Figs. 8 and 9.

In the case under study, the model of scanner which was applied dealt with high humidity and wet or rusted surfaces of the sheet piles. Despite that, differentiation in the surface condition of sheet piles is visible in changing of intensity of the recorded laser signal. It is worth emphasizing that the biggest problems with modelling may occur when we have blank areas or some contaminations in the point clouds.

\section{ACKNOWLEDGMENT}

This work was co-financed from the internal research grant at Wrocław University of Science and Technology (grant No. 0401/ 0211/16).

\section{REFERENCES}

[1] BACA M., MusZYŃSKi Z., RYBAK J., ŻYREK T., The application of geodetic methods for displacement control in the self-balanced pile capacity testing instrument, [in:] Advances and trends in engineering sciences and technologies, International Conference on Engineering Sciences and Technologies, 27-29 May 2015, CRC Press, Tatranská Štrba, Slovakia, 2015, $15-20$.

[2] BaCa M., Rybak J., ŻYreK T., Practical aspects of tubular pile axial capacity testing, [in:] 15th International Multidisciplinary Scientific Geoconference, SGEM 2015, Science and Technologies in Geology, Exploration and Mining, 18-24 June 2015. Vol. 2. Hydrogeology, engineering geology 
and geotechnics, STEF92 Technology, Albena, Bulgaria, 2015, 549-554.

[3] BednáŘová P., Marschalko M., Drusa M., DurĎÁK J., ORININOVÁ L., (2015). Importance of Various Types of Stability Assessment of a Hydrotechnical Structure, [in:] International Multidisciplinary Scientific Geoconference, SGEM 2015, 18-24 June 2015, STEF92 Technology, Albena, Bulgaria, 2015, 383-390.

[4] Gikas V., Paradissis D., Raptakis K., Antonatou O., Deformation Studies of the Dam of Mornos Artificial Lake via Analysis of Geodetic Data, [in:] From Pharaohs to Geoinformatics, FIG Working Week, 16-21 April 2005, Cairo, Egypt, 1-12. Available: https://www.fig.net/resources/proceedings/fig proceedings/cairo/papers/ ts_43/ts43_02_gikas_etal.pdf

[5] KARSZNIA K., Geodezyjny i geotechniczny monitoring obiektów inżynierskich $w$ ujęciu dynamicznym. Wykrywanie stabych punktów, [Electronic version], Nowoczesne Budownictwo Inżynieryjne, 2008, 4(19), 72-75, (in Polish). Available: http:// www.nbi. Com.pl/assets/NBI-pdf/2008/4_19_2008/pdf/23_wykrywanie slabych punktow.pdf

[6] Kersten T., Sternberg H., Mechelke K., Acevedo Pardo C., Terrestrial Laser Scanning System MENSI GS100/GS200 - Accuracy Tests, Experiences and Projects at The Hamburg University of Applied Sciences, [in:] Panoramic Photogrammetry Workshop 2004, TU Dresden, 2004. Available: http://www.isprs. org/proceedings/XXXIV/5-16/papers/panows_Dresden2004 Kersten.pdf

[7] KowalSKa M., ZaCZEK-PePLINSKA J., Roughness parameters as the elements of surface condition and deformation assessment based on the results of TLS scanning, Annals of Warsaw University of Life Sciences-SGGW Land Reclamation, 2017, 49(1), 29-41. Available: http://ann_landreclam.sggw.pl/z491/art3.pdf

[8] MUSZYŃSKI Z., Application of selected robust estimation methods for calculating vertical displacements of hydrotechnical structures, Studia Geotechnica et Mechanica, 2010, 32(1), 69-80. Available: http://www.sgem.pwr.edu.pl/iss/ 2010/no1/art05 no1_2010.pdf
[9] MusZYŃSKi Z., Assessment of suitability of terrestrial laser scanning for determining horizontal displacements of cofferdam during modernization works on the Rędzin sluice, [in:] 14th International Multidisciplinary Scientific Geoconference, SGEM 2014, Geodesy and Mine Surveying, 17-26 June 2014. Vol. 2, STEF92 Technology, Albena, Bulgaria, 81-88.

[10] Popielski P., ZaczeK-Peplinska J., Bartnik E., KasprZAK A., SMOLIŃSKI B., Contemporary techniques of data acquisition for preparation of numerical models of hydrotechnical structures, Czasopismo Techniczne, 2015, 2-Ś, 113-128, DOI: 10.4467/2353737XCT.15.231.4617

[11] Van CranenBroeck J., State of the Art in Structural Geodetic Monitoring Solutions for Hydro Power Dams, [in:] Bridging the Gap between Cultures, FIG Working Week, 18-22 May 2011, Marrakech, Morocco, 2011, 1-18. Available: https:// www.fig.net/resources/proceedings/fig_proceedings/fig2011/ papers/ts01e/ts01e vancranenbroeck 4763.pdf

[12] Van Cranenbroeck J., Brown N., Networking Motorized Total Stations and GPS Receivers for Deformation Measurements, FIG Working Week, 22-27 May 2004, Athens, Greece, 2015, 1-15. Available: https://www.fig.net/resources/ proceedings/ fig_proceedings/athens/papers/ts16/TS16_2_Cranenbroeck_ Brown.pdf

[13] Wan Aziz W.A., ZulKarnaini M.A., Shu K.K., The Deformation Study of High Building Using RTK-GPS: A First Experience in Malaysia, FIG Working Week 2005 and April 2005, GSDI-8, 16-21, 1-11, Cairo, Egypt, 2005. Available: https://www.fig.net/resources/proceedings/fig_proceedings/cairo/ papers/ts_43/ts43_01_wanaziz_etal.pdf

[14] ZACZEK-PEPLINSKA J., FALACIŃSKI P., Evaluation of possibilities to apply laser scanning for estimation of conditions of concrete, Report on Geodesy, 2011, 91(1), 539-546.

[15] ZoGg H.M., (2008). Investigations of High Precision Terrestrial Laser Scanning with Emphasis on the Development of a Robust Close-Range 3D-Laser Scanning System, Dissertation ETH Zurich No. 18013, Zurich, 2008. Available: http://www.igpdata.ethz.ch/berichte/ Blaue_Berichte_PDF/98.pdf 